„Silę ucho”, czyli co słychać

w przekładzie. Niemieckojęzyczne

warianty wiersza Skakanka ufoistki

Mirona Białoszewskiego na tle zabiegów

„przekładania” codzienności na język

poetycki

\title{
Skakanka ufoistki
}

Stoję w oknie.

Coś okropnie

Mną pcha.

$\mathrm{Ja}-\mathrm{z}$ tej strony.

$\mathrm{Z}$ tamtej - wrony

I mgła.

Silę ucho:

Leci UFO

Czy nie?

Mam nadzieję

Że przewieje

I mnie.

Ejże, ejże?!

Coś się bierze...

Coś jest.
Z szyb wygryza

I wysysa

Mnie gdzieś.

Już mnie łapła

Kula światła

W swe rwy.

Do widzenia,

Pani Ziemia!

I wy!

Stamtąd do was

Napiszę

Napiszę

Napiszę

Wiersz Skakanka ufoistki Mirona Białoszewskiego był niegdyś przedmiotem konkursowych zmagań thumaczy uczestników Szkoły Języka, Literatury i Kultury Polskiej Uniwersytetu Śląskiego. Co istotne, powstały dzięki temu nieprofesjonalne przekłady. Owocem spotkania stała się publikacja ${ }^{2}$, która jest

${ }^{\text {I }}$ M. Białoszewski, Rozkurz, Warszawa 1980, s. 227.

${ }^{2}$ M. Białoszewski, Skakanka Ufoistki: zbiór przektadów na jezzyki obce. Turniej Thumaczy '96, red. J. Grzenia, Cieszyn 1996. Do tego samego zbioru, tyle 
punktem wyjścia moich rozważań nad przekładalnością twórczości Białoszewskiego, nad rolą przekładu w interpretacji i rolą interpretacji w przekładzie. Prześledziłam pięć dostępnych przekładów tego samego wiersza na jeden język. Potraktowałam je, za Edwardem Balcerzanem, jako „serię wielowariantową, której składnikiem staje się przekład" ${ }^{3}$. Skoncentrowałam się zwłaszcza na tym, w jaki sposób w przekładach oddany został język codzienny. Bardzo istotnym poruszanym przeze mnie kręgiem tematycznym jest bowiem przekładalność codziennego doświadczenia, nierzadko epifanijnego, na język artystyczny - język poezji bądź prozy. To jeden z głównych motywów twórczości Białoszewskiego; sam Autor w jednym z wierszy zamieszczonych w Rozkurzu, Dobrze mi tam było?, wyznaje: „Ja naprawdę uwierzyłem, że to do przełożenia" 4 .

\section{Zabiegi „przekładania” codzienności}

Twórczość Białoszewskiego w przeważającej części dałaby się podporządkować raczej prostej i modnej $\mathrm{w}$ antropologii codzienności tezie: codzienność ma wartość. Kluczowy był bowiem dla poety problem literackiej realizacji zwykłej mowy. Zwykła mowę definiuję tu za Walentinem Wołoszynowem, który używa $\mathrm{w}$ tym kontekście terminu potoczna mowa życiowa w znaczeniu wypowiedzi słownej spoza sztuki, w której to wypowiedzi kryją się możliwości przyszłej formy artystycznej ${ }^{5}$. Michaił Bachtin pisał z kolei o słowie jako zjawisku społecznym, o społecznym życiu słowa, języku dni, a nawet godzin, o żywym języku, żywej różnojęzycznej mowie ${ }^{6}$. Co istotne, ani Wołoszynow, ani Bachtin nie używali wymienionych określeń jako terminów $\mathrm{w}$ sensie ścisłym.

że w odniesieniu do tłumaczeń na język angielski, czeski, francuski, rosyjski, słowacki i ukraiński, odwołuje się Piotr Sobolczyk (zob. idem, Język potoczny Białoszereskiego w przektadzie, „Między Oryginałem a Przekładem”, t. 12: Głos i dźrwięk w przekładzie, red. J. Brzozowski, J. Konieczna-Twardzik, M. Filipowicz-Rudek, Kraków 2006, s. 81-84.

3 E. Balcerzan, Wstep, w: idem, Pisarze polscy o sztuce przektadu, Poznań 1977, s. 18.

4 M. Białoszewski, Rozkurz, s. 153.

5 W. Wołoszynow, Stowo w zyciu i stowo w poezji. Przyczynek do zagadnień poetyki socjologicznej, tłum. A. Pomorski, w: Ja - Inny. Wokót Bachtina, t. 1, red. D. Ulicka, Kraków 2009, s. 100.

${ }^{6}$ M. Bachtin, Stowo w powieści, w: idem, Problemy literatury i estetyki, thum. W. Grajewski, Warszawa 1982, s. 82-277. 
Podejmowana tematyka mowy codzienności mieści się w znacznie szerszej kategorii: poetyki codzienności7. Jolanta Brach-Czaina, filozofka i antropolożka, która podjęła tę problematykę w Szczelinach istnienia ${ }^{8}$, ma do przejawów codzienności stosunek, rzec można, kontemplacyjny. Eseistyczne ujęcie ${ }^{9}$ pozwala wyodrębnić przedmioty oraz sytuacje powszednie i poświęcić im należytą uwagę, mimowolnie je uwznioślić, jak w bliskim autorce postsymbolizmie literackim i filozoficznej hermeneutyce. Metodę swoją nazywa Brach-Czaina odnajdywaniem drobin bytu ${ }^{\text {Io }}$. Stają się nimi przedmioty, zjawiska oraz elementy codziennej krzątaniny - gotowanie, sprzątanie, a nawet próba dogonienia odjeżdżającego autobusu. Trzeba zauważyć jednocześnie, że kultu codzienności nie sposób dopatrzeć się w języku tej prozy, podobnie jak nie było widać tej zależności w rozważaniach

7 Zwięzły przegląd stanowisk badawczych literaturoznawstwa znalazł się w artykule Grażyny Borkowskiej (zob. eadem, Życie codzienne jako kategoria literacka i badawcza (rekonesans), w: Codzienność w literaturze XIX $(i X X)$ wieku. Od Adalberta Stiftera do wspótczesności, red. G. Borkowska, A. Mazur, Opole 2007, s. 30-38). Cenna jest zwłaszcza teza redaktorek tomu, że kategoria codzienności w literaturze, typowa dla formacji postmodernistycznej, ma swoje początki $\mathrm{w}$ wieku XIX: w biedermeierze z jego apoteozą umiaru, w nieortodoksyjnym romantyzmie, następnie w realizmie i modernizmie (zob. A. Mazur, G. Borkowska, Stowo wstepne, w: Codzienność w literaturze, s. 7-15). Teza ta zostaje tu wspomniana głównie dlatego, że zainteresowanie codziennością stanowiłoby kolejny wątek łączący Białoszewskiego z XIX-wieczną tradycją - obok modelu poety (do pewnego przynajmniej momentu) biednego (zob. M. Łukaszuk-Piekara, ,niby ja”. O poezji Mirona Białoszewskiego, Lublin 1997, s. 14) oraz ideału jedności życia i literatury (zob. K. Rutkowski, Przeciw (w) literaturze. Esej o ,poezji czynnej” Mirona Białoszewskiego i Edwarda Stachury, Bydgoszcz 1987). O tym, że ballada o wydarzeniach dnia codziennego, eksploatowana twórczo przez Białoszewskiego, była jedną z podstawowych form poetyckich dogasającego romantyzmu, wspomina też Michał Głowiński (zob. idem, Małe narracje Białoszewskiego, w: idem, Gry powieściowe. Szkice z teorii i historii form narracyjnych, Warszawa 1973, s. 320). Zainteresowanie codziennością łączy Białoszewskiego również z poetami dwudziestolecia międzywojennego - z polską awangardą i z jej francuskimi korzeniami, a tematycznie i niejako powierzchownie ze skamandrytami, którzy wprowadzili do poezji realia codzienności, słownictwo oraz szyk zdania języka codziennego (zob. I. Maciejewska, Wstęp, w: Poeci droudziestolecia międzywojennego, t. 1, red. I. Maciejewska, Warszawa 1982, s. 16-24). Istotny jest semiologiczny kontekst tematyki codzienności, a także konteksty: antropologiczny, filozoficzny (zwłaszcza filozofii języka) oraz językoznawczy.

8 J. Brach-Czaina, Szczeliny istnienia, Kraków 2008.

9 Analogiczną do użytej w Szczelinach istnienia (pierwsze wydanie: Warszawa 1992) metodę badawczą wykorzystuje autorka także w późniejszych Błonach umystu (Warszawa 2003).

ro Konieczne jest krótkie wyjaśnienie terminologii wprowadzonej w cytowanym eseju. Przez fragment rzeczywistości rozumie Brach-Czaina „część wycinaną z całości arbitralnie”, podczas gdy drobiny bytu „same domagają się uwagi. Istnienie zagęszcza się w nich w konkret egzystencjalny, który nie powinien być lekceważony" (J. Brach-Czaina, Szczeliny istnienia, s. 11). 
Wilhelma Diltheya, Edmunda Husserla i Martina Heideggera o Lebenswelt ${ }^{\text {II }}$. Inaczej mówiąc, codzienność była w przywoływanych tekstach tematyzowana, jednak autorzy nie stawiali sobie za cel używania czy przywoływania przy tym codziennego języka, który jest przecież najwnikliwszym sondażem i najlepszą artykulacją codzienności. Nie można pominąć tu także filozofii języka Heideggera, w której centrum stało pojęcie mowy (Rede), rozumianej jako źródłowa wysławialność świata, jego pierwotne znaczenie $^{\mathrm{I} 2}$.

II Lebenswelt to termin wprowadzony w ostatnim dziele Edmunda Husserla Kryzys nauk europejskich i fenomenologia transcendentalna (1937), antycypowany zaś w filozofii między innymi przez Kanta, Nietzschego czy Schellera: „Filozoficzne myślenie o świecie coraz bardziej oddalało się od idei kosmosu i przyrody, a skupiało się na historycznej, językowej i społecznej egzystencji człowieka. Tendencja ta osiągnęła punkt szczytowy w filozofii Husserla” (Z. Krasnodębski, K. Nellen, Wstep, w: Swiat przeżywany. Fenomenologia i nauki społeczne, Warszawa 1993, s. 8). Wskazani autorzy oddają niemiecki termin Lebenswelt przez świat przeżywany i definiują go jako ogólną, pierwotną strukturę świata, ukonstytuowaną $\mathrm{w}$ doświadczeniu przednaukowym, utożsamianą przez Husserla z daną naocznie przyrodą (zob. ibidem, s. 17). Inne thumaczenie terminu świat życia codziennego - stosowali Jan Szewczyk, a także Krystyna Święcicka (za przekładem Sławomiry Walczewskiej). Następująco definiował Lebenswelt sam Husserl: „Jest on czasowo przestrzennym światem rzeczy, jakich w naszym przednaukowym i pozanaukowym życiu doświadczamy, oraz takich, o jakich wiemy, że wykraczają poza te, których doświadczamy, ale które mogą być dane w doświadczeniu. Posiadamy horyzont świata jako horyzont możliwego doświadczenia rzeczy” (E. Husserl, W jaki sposób po dokonaniu „epoché” wodniesieniu do nauk obiektywnych świat naszego życia codziennego może stać się tematem nauki? Zasadnicze rozró̇̇nienie a priori obiektywono-logicznego $i$ a priori świata naszego życia codziennego, w: idem, Kryzys nauki europejskiej a transcendentalna fenomenologia, tłum. J. Szewczyk, przejrzał i zinterpretował terminy R. Ingarden, „Studia Filozoficzne” 1976, nr 9, s. 108). Na tej podstawie postawił filozof „wielkie zadanie utworzenia czystej nauki o istocie świata codzienności” (ibidem, s. 110). Rolę codzienności dla fenomenologii trafnie oddał Krzysztof Michalski, stwierdzając, że „w opisie fenomenologicznym mamy do czynienia dokładnie $\mathrm{z}$ tym światem, z którym mamy do czynienia na co dzień - tyle że ujętym $\mathrm{z}$ innego punktu widzenia: $\mathrm{z}$ punktu widzenia zjawiania się, a nie tego, co się w nim zjawia. Fenomenologia jest w tym podobna do sztuki; i sztuka przecież pozwala nam spojrzeć innymi oczyma na to samo, co widzimy na co dzień" (K. Michalski, Heidegger i fenomenologia, w: idem, Heidegger i filozofia wespótczesna, Warszawa 1978, s. 13). Najwcześniej jednak to Dilthey starał się dotrzeć do sensu dziania się życia, które jako niepotrzebujące żadnych uzasadnień uznawał za dowód realności zewnętrznego świata (zob. Z. Kuderowicz, Dilthey, Warszawa 1967, s. 70).

I2 „Mowa to wysławialność świata - możliwość tego, że rzeczy dadzą się wysłowić, a słowa będą mieć znaczenie. Język to wypowiadalność mowy - możliwość wypowiedzenia tych znaczeń za pomocą słów” (W. Rymkiewicz, Stowo: mowa egzystencji, w: idem, Ktoś i nikt. Wprowadzenie do lektury Heideggera, Wrocław 2002, s. 128). Autor pokazuje, jak Heidegger w Sein und Zeit zaczą budować swoją filozofię języka, wyrażoną następnie najpełniej w zbiorze późnych esejów Unterwegs zur Sprache. W jednym z nich czytamy, że na mowę składa się zasłyszane: „Śmiertelni mówią, o ile słuchają” (M. Heidegger, Język, w: idem, W drodze do jezyyka, thum. J. Mizera, Warszawa 2007, s. 25). 
Odwołując się do terminów wprowadzonych przez BrachCzainę, drobiną znaczącą jest w takim rozumieniu, jakie przyjęłam w analizie twórczości Białoszewskiego, mowa codzienności, a szczeliną, przez którą w nią wnikniemy - seria przekładowa. Zabieg taki wydaje się uprawniony i niesprzeczny $\mathrm{z}$ intencjami autora, który sam wielokrotnie podkreślał, jak duże znaczenie miał dla niego szczegół, drobiazg, w tym także zasłyszany dialog. W jednym z wywiadów mówił: „[...] ile rzeczy na raz się dzieje, obok siebie, po kolei czy nie po kolei. Dochodzenia, skojarzenia, sytuacje dialogowe, jakieś historie. Poprzez moje odczucia jeszcze. [...] Ważne są wszystkie szczególiki, bo inaczej to nie będzie nasycone" ${ }^{\text {I3. }}$

Nie pierwszy raz oczywiście pojawia się w odniesieniu do Białoszewskiego taki „codziennościowy” trop interpretacyjny. Niech za dowód posłużą przytoczone in extenso słowa Michała Głowińskiego z referatu wygłoszonego podczas poświęconej poecie konferencji w Instytucie Badań Literackich PAN:

Wiadomo, codzienność jest główną dziedziną Białoszewskiego, nawet to bowiem, co poza nią wykracza, jest tak czy inaczej w niej osadzone. Literacką codzienność rozumie się zwykle tak, jakby była sprawą tematów i realiów. Ujmowana w ten sposób, stanowi domenę powieści, odkąd zerwała ona z tradycjami romansu przygodowego, a także poezji, która od pewnego momentu manifestacyjnie uwolniła się od wszelkiej hierarchii tematów. Nie ulega wątpliwości, że tak tradycyjnie interpretowana codzienność nie przylega już do Białoszewskiego, nie ogranicza on jej bowiem do tematów czy przedmiotów. Można wstępnie stwierdzić, że u niego codzienność jest w pewien sposób formą mówienia, że to sam akt mowy staje się jej przekazem, a więc jest ona czymś więcej niż zewnętrzną wobec niego sytuacją ${ }^{\mathrm{I}}$.

Dla uniknięcia nieporozumień trzeba tu wspomnieć, że mowa codzienności $w$ znaczeniu przyjętym w tym szkicu nie jest ani językiem mówionym ${ }^{15}$, ani językiem potocznym ${ }^{16} \mathrm{w}$ rozumie-

${ }^{13}$ Z. Taranienko, Szacunek dla każdego drobiazgu, w: idem, Rozmowyzpisarzami, Warszawa 1986, s. 402.

${ }_{4}$ M. Głowiński, Białoszewskiego gatunki codzienne, w: Pisanie Białoszewskiego. Szkice, red. M. Głowiński, Z. Łapiński, Warszawa 1993, s. 144.

${ }_{5}$ Charakterystyczna dla języka mówionego jest duża swoboda użytkownika skutkująca tym, że teksty mówione zawierają o wiele więcej odwołań do konkretnej życiowej sytuacji (zob. Z. Saloni, Język mówiony [hasło], w: Encyklopedia jezzykoznawestwa ogólnego, red. K. Polański, Wrocław 2003, s. 271). Właśnie kontekstowość i sytuacyjność języka mówionego były uwypuklane przez pisarstwo Białoszewskiego.

${ }^{16}$ Przez język potoczny rozumiem przeciwstawianą językowi literackiemu ogólnonarodową odmianę języka, o niższym stopniu zdyscyplinowania, wystę- 
niu językoznawczym. W pewnym zakresie termin jest zbieżny z tymi dwoma pojęciami, ale pozostaje od nich odmienny przez to, że sytuuje się w horyzoncie antropologicznym i teoretycznoliterackim, a nie tylko językoznawczym ${ }^{77}$.

Stosowaną przez siebie metodę twórczą Białoszewski tematyzował wielokrotnie. W taki sposób w Szumach, zlepach, ciagach naprowadzał czytelnika na swoje nieustanne dążenie do schwytania rzeczywistości na gorącym - od pewnego momentu przede wszystkim językowym - uczynku: „Wpadam w tramwaj. Zapisuję. Wysiadka, wysepka, zapisuję. Na Foksal też. Który to autor robi przed wydawnictwem? A ja jeszcze piszę na schodach" ${ }^{18}$.

W filmie Paręosób, mały czas, powstałym na podstawie pamiętników Jadwigi Stańczakowej ${ }^{\text {I9 }}$, niewidomej przyjaciółki Białoszewskiego, widzimy pisarza wyruszającego na swoje słynne warszawskie spacery $-\mathrm{z}$ magnetofonem. Rejestrowane $\mathrm{w}$ ten sposób naprędce wrażenia były następnie spisywane, od pewnego momentu nie przez samego poetę. Magnetofon, widomy znak pisania ze słuchu, pojawia się zarówno w Dzienniku we dwoje, jak i w innych wspomnieniach o Białoszewskim, a także w jego prozie ${ }^{20}$. W drugiej części tego krótkiego szkicu postaram się na przykładzie wiersza Skakanka ufoistki pokazać, o ile trudniej daje się przełożyć utwór będący tak rozumianym „podwójnym przekładem”.

\section{Skakanka ufoistki w przekładach na język niemiecki}

Wiersz Skakanka ufoistki, będący swoistym poetyckim żartem pochodzącym z Kabaretu Kici Koci, został przez autora zamiesz-

pującą głównie w wersji mówionej (zob. K. Polański, Język potoczny [hasło], w: Encyklopedia językoznawstwa ogólnego, s. 273).

${ }_{17}$ Jako kontrprzykład podać można kanoniczną już pracę Stanisława Barańczaka Język poetycki Mirona Białoszereskiego (Wrocław 1974). Autor, po części dla potwierdzenia klasyfikacji Białoszewskiego jako poety lingwistycznego, badał głównie język jego twórczości. Podobnie Henryk Pustkowski analizował komponenty języka Białoszewskiego jako języka parodystycznego wobec postulatów Awangardy Krakowskiej odnośnie do budowy ekonomicznego języka poetyckiego (zob. H. Pustkowski, Trzy razy Miron Białoszeweski, w: idem, Gramatyka poezji, s. 58-104).

${ }_{18}$ M. Białoszewski, Szumy, zlepy, ciagi, Warszawa 1976, s. 5.

I9 J. Stańczakowa, Dziennik we dwoje, Warszawa 1992; eadem, Dziennik we dwoje, t. 2, Warszawa [b.d.].

${ }_{20}$ „Możemy wziąć magnetofon, tylko pada” (M. Białoszewski, Zawat, w: idem, Utwory zebrane, t. 6, Warszawa 1991, s. 239). „Zainteresuje Pana zapewne, że Miron od kilku lat przeszedł na „nagadywanie” tekstów, zwłaszcza prozy, do magnetofonu. Dyktował «z głowy» od razu ze znakami przestankowymi. A przepisywała jego teksty $\mathrm{z}$ taśmy na maszynę wynaleziona przeze mnie niewidoma maszynistka” (J. Stańczakowa, Listy do Czestawa Miłosza, „Zeszyty Literackie” 2009, nr 106, s. 48 - list z 5 listopada 1983 r.). 
czony w tomie Rozkurz. Pojawia się w nim istotny dla twórczości Białoszewskiego i często w niej spotykany motyw nasłuchiwania:

Silę ucho:

Leci UFO

Czy nie?

Dzięki porównaniu kilku dostępnych przekładów nie tylko można zaobserwować różne odcienie znaczeniowe zastosowanego przez poetę w Skakance ufoistki związku frazeologicznego „silić ucho", ale da się też, na przykładzie sposobu tłumaczenia typowo potocznych zwrotów, tropić żywioł mowy codziennej. „Przekład artystyczny - jeśli chce rzeczywiście zachować prawo do takiego miana - musi być swoistą rekonstrukcją modelu świata implikowanego w tekście oryginału" - podaje w jednej z rozpraw Stanisław Barańczak ${ }^{2 I}$. Wyjaśnia następnie, co składa się na ów model świata. W przypadku tekstu poetyckiego istotnym jego elementem pozostaje „wewnątrztekstowa sytuacja komunikacyjna” ${ }^{22}$. Podobnie twierdzi Balcerzan, kiedy powiada: „Przekład nie ma osobnej przestrzeni, zawsze istnieje wewnątrz i zawsze dla wartości prymarnych, uformowanych wcześniej” ${ }^{23}$.

Joanna Pochron tytułuje swój przekład Reim einer Ufologin ${ }^{24}$ i oddaje zwrot „silić ucho” przez die Obren summen. Czasownik summen ma w języku niemieckim podstawowe znaczenie „sumować, dodawać” ${ }^{25}$. Drugim dopiero odpowiednikiem jest „szumieć" (o owadach, wentylatorze) „nucić” lub „płynać” (o muzyce). Jeżeli tłumaczce chodziło o takie właśnie rozumienie słowa, to mamy do czynienia z ciekawą sytuacją, gdy dźwięk jest tak intensywnie odbierany, że słyszący go ma wrażenie, jakby szumiało mu w uszach. Prostsze wytłumaczenie może odnosić się do tego, że uszy „sumują”, a więc zbierają dochodzące $\mathrm{z}$ otoczenia sygnały.

Najbliższe wersowi Białoszewskiego wydają się autorki przekładu pod tytułem Auszäblereim einer Ufoistin - Julia Karsay

${ }^{21}$ S. Barańczak, Poetycki model świata a problemy przekładu artystycznego (na materiale polskich thumaczeń G.M. Hopkinsa), w: Wielojęzyczność literatury i problemy przekładu artystycznego, red. E. Balcerzan, Wrocław - Warszawa - Kraków - Gdańsk - Łódź 1984, s. 207.

${ }^{22}$ Ibidem, s. 208.

${ }_{23}$ E. Balcerzan, Stowo wstępne, w: Wielojęzyczność literatury, s. 8.

${ }_{24}$ M. Białoszewski, Reim einer Ufologin, tłum. J. Pochron, w: idem, Skakanka Ufoistki, s. 23.

${ }_{25}$ Wszystkie przytoczone w tekście definicje słownikowe podaję za: Das große DUDEN Wörterbuch der deutschen Sprache in 10 Bänden, Mannheim - Leipzig - Wien - Zürich 1999. 
i Agata Błaszczyk ${ }^{26}$; być może ze względu na przekładową współpracę osób: niemiecko-i polskojęzycznej. Użyły one niemieckiego frazeologizmu die Obren spitzen, który zdaje się leżeć u podstaw językowej transformacji dokonanej przez Białoszewskiego. Jego „silić ucho” jest bowiem, moim zdaniem, bliską, choć nie w pełni tożsamą, wersją polskiego frazeologizmu „nadstawić ucha/uszu”, za pomocą którego można by przetłumaczyć powyższy niemiecki odpowiednik.

W zupełnie inną stronę kieruje na poły anonimowy przekład (tłum. Anna i Günter) zatytułowany Hoppla, boppla beia des Ufoliebchens ${ }^{27}$. Pojawia się w nim czasownik horchen („próbować dosłyszeć”, ale też: „słuchać z wielką uwagą”) w trybie rozkazującym, w liczbie pojedynczej. Interesujący nas fragment brzmi więc: „Wsłuchaj się!”. Choć w analizowanym wierszu Białoszewskiego nie znajdziemy trybu rozkazującego, w przekładzie podmiot liryczny sam formułuje wobec siebie nakaz. Zupełnie jakby chciał zweryfikować swoje przypuszczenia, jakby zastanawiał się: „Czy aby dobrze słyszę, że zbliża się do mnie niezidentyfikowany obiekt latający?” Na tym przykładzie widać, w jaki sposób z czegoś, co na początku utworu podmiotem „okropnie pcha”, w przekładzie uczyniono językowy nakaz, równocześnie $\mathrm{w}$ jednym miejscu do oryginału się przybliżając, a w innym od niego oddalając.

Dwa przekłady analizowanego fragmentu mają u podstaw czasownik lauschen, który ma przede wszystkim znaczenie „podsłuchiwać”. Wpisane jest weń działanie po kryjomu, co doskonale wykorzystał Klaus Jürgen Gentsch ${ }^{28}$. Użył formy imiesłowowej lauschend i oddał polski zwrot „silę ucho” za pomocą Obr jetzt lauschend. Tym, co podsłuchuje, staje się więc samo ucho. Czynność człowieka przeniesiona zostaje na organ słuchu. Zupełnie jak w Nadwołokowyjskiej nocy liczbie pojedynczej ${ }^{29}$, gdzie „ucho wilka wyło do wiatru”. „Podsłuchujące teraz ucho, powiedz mi czy nadlatuje UFO?” - można by w przybliżeniu oddać przedstawiony tutaj przekładowy pomysł.

Jeszcze bardziej pomysłowo zakres znaczeniowy czasownika lauschen wykorzystał Ralf Heckhausen ${ }^{3}$, który odwołał się do

${ }^{26}$ M. Białoszewski, Auszäblereim einer Ufoistin, thum. J. Karsay, A. Błaszczyk, w: idem, Skakanka Ufoistki, s. 29.

${ }_{27}$ M. Białoszewski, Hoppla, Hoppla heia des Ufoliebchens, thum. Anna i Günter, w: ibidem, s. 27.

${ }_{28}$ M. Białoszewski, Am Fenster stehe ich, thum. K.J. Gentsch, w: ibidem, s. 25.

29 M. Białoszewski, Rachunek zachciankowy, Warszawa 1959, s. 7.

$3^{\circ}$ M. Białoszewski, Seilspringende UFO-istin, thum. R. Heckhausen, w: idem, Skakanka Ufoistki, s. 31. 
terminologii myśliwskiej i nasłuchującemu podmiotowi nadał cechy zwierzęce. Użył rzeczownika Lauscher, w liczbie mnogiej i jedynym możliwym w języku niemieckim znaczeniu ${ }^{3 \text { I }}$. Ich spitze die Lauscher, czyli „nadstawiam uszu”, jest konstrukcyjnie bardzo bliskie przywołanemu na początku tłumaczeniu $i c h$ spitze die Obren, a jednak otwiera zupełnie inne rejony interpretacyjne. Stojący w oknie - skoro na mocy poetyckiej figury ma fizyczną cechę dzikich zwierząt, ich uszy - zachowuje się jak nieufne zwierzę. Więcej: jest nieufnym zwierzęciem. Nasłuchuje i nie wie, czego się spodziewać; odczuwa być może zagrożenie. Takie ewentualności nie były wpisane we wcześniejsze tłumaczenia.

Każda z przywołanych wersji na swój sposób wskazywała na nowe, nieco inne odcienie znaczeniowe, nie zawsze znajdujące się w centrum użytego przez Białoszewskiego sformułowania. Wszystkie z podobną siłą podkreślały podstawowy dla całego wiersza element nasłuchiwania i napięcia. Nie bez przyczyny Białoszewski wybrał zwrot „silić ucho” i nie bez powodu zwrócili na niego uwagę wszyscy tłumacze. Odsyła on przecież do bliskiego związku frazeologicznego „wytężać słuch”, a sam bezokolicznik „silić” jest jednocześnie wstecznym derywatem od „wysilać”, czyli „usilnie próbować”. Natężenie i wykonana w związku z tym praca są tu więc kluczowe. Białoszewski, jakby na marginesie swego poetyckiego żartu, zdaje się mówić: to, co usłyszysz, zależy od tego, jak uważnie będziesz słuchać, ile pracy (siły) włożysz w sam akt nasłuchiwania.

Do ciekawych wniosków prowadzi także rozpatrzenie thumaczenia następujących wersów:

Ejże, ejże?!

Coś się bierze...

Coś jest.

oraz

Do widzenia,

Pani Ziemia!

I wy!

W obu przypadkach mamy do czynienia z typowymi dla języka potocznego konstrukcjami - wykrzyknieniem oraz z uży-

$3^{\text {I }}$ Niem. Lauscher - uszy dzikich zwierząt racicznych, między innymi lisów, wilków, bobrów. 
ciem mianownika zamiast (i w funkcji) wołacza. Różnie oddali to thumacze ${ }^{32}$.

$\mathrm{W}$ języku niemieckim, dysponującym tylko czterema przypadkami, nie ma możliwości zmiany formy mianownika na formę wołacza (nie da się więc powiedzieć: „Do widzenia, Kasiu”, a jedynie: „Do widzenia, Kasia”). Pewnie dlatego tylko jeden z thumaczy dostrzegł, że użycie przez Białoszewskiego mianownika ma wskazywać na nieskrępowanie polskiej normy potocznej33. Heckhausen przetłumaczył ten wers niemieckim odpowiednikiem potocznego pożegnania, mianowicie: Machs gut, Frau Erde!, co znaczy w przybliżeniu „Trzymaj się, Pani Ziemio!”

Zupełnie odwrotnie stało się w przypadku wykrzyknienia. We wszystkich pięciu cytowanych tu przekładach dostrzeżono żywioł potoczności, codzienności i dowolności, na który otwiera sformułowanie „Ejże, ejże”, poddające się dowolnej wręcz interpretacji. Możliwości jest mnóstwo, zwłaszcza jeśliby zważyć na następujące po sobie w zakończeniu wersu znaki interpunkcyjne pytajnik i wykrzyknik. Nieograniczoną liczbę możliwych odczytań sygnalizuję tylko przez podanie wybranych przez thumaczy ekwiwalentów niemieckich: Trali, Tralala?!, Hey, bey?!, Schau! Was ist das! („Spójrz! Co to jest!”), Ach, ach?! Niedaleka od tego wyliczenia droga do nazwania uczuć i przeczuć, które kryć się mogą za takimi sformułowaniami. Słownik podaje, że dla niemieckojęzycznego użytkownika za słowem achstać może, w zależności od kontekstu $\mathrm{i}$ intonacji, żal, współczucie, empatia, zrozumienie, z kolei zwrotu beyużyć można, by przykuć czyjąś uwagę, zaskoczyć, pozdrowić, czasem nawet zaatakować lub odeprzeć atak. Bardzo trafnie w żywiole polskiej mowy pokazuje to Jerzy Bralczyk, gdy w książce słowniczku Mójjęzyk prywatny podaje:

Daleko gdzieś, hej, jak daleko. Trzeba głośno wołać. Hej!!! Za daleko. Daleko, że hej. [...] Jak wołam, to do kogoś i po coś. „Hej, strzelcy wraz!” [...] Bo jak tak wołam „hej”, to i do siebie wołam [...] i - hej! do roboty idę. Ale bywa, że jak wołam „hej”, to nie wzywam do czegoś, tylko przeciwnie. Żeby ktoś czegoś nie robił [...]. Wtedy jest to takie ostrzeżenie. Hej, z drogi! Kiedy Cię zobaczę, wołam „hej, cześć, co słychać?” A Ty mi na to spokojnie „no hej”. I, że nic, jak się okazuje, nie słychać, mówimy sobie „no to hej” i idziemy sobie $[. .].]^{34}$.

${ }^{22} \mathrm{O}$ problemie z oddaniem w thumaczeniu Skakanki ufoistki wykrzyknień oraz mianownika w funkcji wołacza, a także potocznego wyrażenia „łapła” pisał Piotr Sobolczyk (zob. op.cit., s. 82).

33 Może być to także nawiązanie do mowy dziecka.

34 J. Bralczyk, Mój język prywatny. Stownik autobiograficzny, Warszawa 2004, s. 100. 
Zwrot Trali, Tralala?! na pierwszy rzut oka wydaje się tu mniej stosowny niż wspomniane wykrzykniki beylub ach. Okazuje się jednak, że może być cennym tropem interpretacyjnym. Swój poetycki żart Białoszewski nie bez przyczyny zaty tułował Skakanka; nie przypadkiem tak silnie go zrymował i zrytmizował. Odwołuje się przecież do dziecięcych gier i wyliczanek, które są jednym z możliwych podsłuchanych ech podwórkowej codzienności. Być może nawet językową grą $\mathrm{w}$ rozumieniu nadanym przez Ludwiga Wittgensteina ${ }^{35}$.

Do takiego kontekstu odsyła także w przypadku jednego z przekładów na pozór niepasujący tu zaśpiew Trali, Tralala?! Mirosław Bańko we Wspótczesnym polskim onomatopeikonie jako literackie przykłady użycia onomatopei tra-la-la podaje między innymi Jasia $i$ Matgosię Brzechwy oraz O panu Tralalińskim Tuwima, wiążąc tym samym opisywaną onomatopeję z dziecięcą, i nie tylko dziecięcą, zabawą ${ }^{36}$. Tak też, jakże celnie, uczyniła tłumaczka37.

Każdy z przekładów omawianych w tym krótkim szkicu odkrył wiele możliwości interpretacyjnych „zmagazynowanych w cudzej mowie" ${ }^{8}$, w mowie Białoszewskiego i przez Białoszewskiego swoiście przetłumaczonej. Eksperyment ten można uznać za uprawniony, skoro sam poeta był tropicielem przekładowych drobiazgów - tego, co między językami się gubi, a co zostaje przez thumacza uwypuklone. W Chamowie znajdujemy takie oto fragmenty:

„Durchschnitlich” - przeciętnie. Mówię, że to dosłowne thumaczenie, kalka - ale może być przecięciowo, to już malutka możliwość odmiany. [...] „Respublica” - rzecz pospolita, jesteśmy pewni, że to

35 „ «Grą językową» nazywać też będę całość złożoną z języka i z czynności, w które jest on wpleciony" (L. Wittgenstein, Dociekania filozoficzne, thum. B. Wolniewicz, Warszawa 2005, s. 12).

${ }^{6}$ M. Bańko, Wspótczesny polski onomatopeikon. Ikoniczność w języku, Warszawa 2008, s. 251-252.

37 Chodzi o tłumaczenie Joanny Pochron. Warto tu przywołać też uwagę interpretacyjną Romualda Cudaka, który uznał, że tytułowa skakanka może być odczytana jako typowa dla Białoszewskiego propozycja nowego gatunku: skakanka - wyliczanka dziecięca (zob. R. Cudak, Czytając Białoszeweskiego, Katowice 1999 , s. 260-261).

$3^{8}$ E. Balcerzan, Wstę, w: Pisarze polscy o sztuce przektadu, s. 24. 
dosłowna tożsamość, tymczasem co to jest pospolita? pospołu lita (jak jednolita) ${ }^{39}$.

Powyższa cząstkowa analiza pokazała przede wszystkim, że dominanta mowy codzienności, w tym przypadku wyrażanej (inaczej niż było to na przykład w Obrotach rzeczy) przez same zabiegi językowe, faktycznie istnieje w twórczości Białoszewskiego tak wyraźnie, że tłumacze niemal bez wyjątku podejmują próby oddania jej w przekładach. Niestety często okazuje się, że ta dominanta jest ze względu na wpisaną w nią jednostkowość i niepowtarzalność nie do przełożenia ${ }^{40}$. Dużo łatwiej oddać rytm i rym niż to, jak podmiot „, sili ucho”, co w związku z tym słyszy i jak nawołuje, by usłyszeć więcej.

\section{AlEKSANDRA BURBA}

"I strain my ear", or what can be heard in translation.

German variants of the poem Ufo Agent's Skipping Rope by

Miron Białoszewski, with reference to his technique of “translating” everyday life into poetic language

The article has been derived from a chapter of an MA thesis on everyday speech in Miron Białoszewski's work. The text focuses on exposition of methodological assumptions - the notion of everyday speech and its translation into poetic language in Białoszewski's works. In particular, the article discusses a series of non-professional translations of the poem UFO agent's skipping rope into German, as an example of the functioning of the dominant of everyday speech in translations of Białoszewski's poetry.

Keywords: everyday life in poetic language, everyday speech, Miron Białoszewski's poetry, non-professional translation into German.

Aleksandra Burba - doktorantka na Wydziale Polonistyki UJ, absolwentka Wydziału Polonistyki oraz Wydziału Prawa i Administracji UW, a także podyplomowych studiów edytorskich. Specjalista do spraw prawnych w Stowarzyszeniu Autorów i Wydawców „Polska Książka”, aplikantka

39 M. Białoszewski, Chamowo, w: idem, Utwory zebrane, t. 11, Warszawa 2009, s. 123.

$4^{\circ}$ O nieprzetłumaczalności prozy Białoszewskiego pisał Czesław Miłosz: „Mowa, która żongluje osobliwością fleksji i wielką liczbą przypadków, nie może być oddana w obcym języku i Białoszewski jest w zasadzie nieprzetłumaczalny, tym bardziej że w miarę upływu lat zwiększa się jego skłonność do urywkowego, stenograficznego zapisu" (C. Miłosz, Ruiny i poezja, w: idem, Świadectwo poezji. Sześć wyktadów o dotkliwościach naszego wieku, Warszawa 1987, s. 90). 
„Silę ucho”, czyli co słychać w przekładzie $\mathbf{2 0} 3$

radcowska w Okręgowej Izbie Radców Prawnych w Krakowie. W zakresie jej badań i zainteresowań literaturoznawczych pozostaje zwłaszcza tematyka przekładowa w kontekście poezji polskiej XX w. i niemieckiego kręgu językowego.

www.cash.polonistyka.uj.edu.pl 